UDC: 821.111(680).09-31 Куци Џ. М.

\title{
HYBRIDITY IN J. M. COETZEE'S WAITING FOR THE BARBARIANS
}

\author{
BOJANA GLEDIĆ ${ }^{1}$ \\ University of Belgrade, \\ Faculty of Philology, English Department, \\ Belgrade, Serbia
}

U svetu kolonijalizma, granična linija koja razdvaja prostor kolonizatora i onoga ko je kolonizovan jasno je vidljiva. U takvoj postavci, ponekad dolazi do pojave ničije zemlje kojom obitavaju hibridi. Ovaj rad istražuje mogućnost postojanja tekućeg procesa hibridizacije u romanu Dž. M. Kucija iz 1980. godine Iščekujući varvare. Rad daje pregled definicija termina hibrid, kao i njegove upotrebe, i predstavlja moguću primenu takvog termina na lik Načelnika u datom romanu. Uzeti su u obzir različiti upitni i višeznačni aspekti ponašanja ovog lika, i dolazi se do zaključka da su oni pokazatelj da do kraja romana bez sumnje dolazi do pojave znakova hibridnosti u liku Načelnika.

Ključne reči: kolonijalni identitet, superiornost, drugost, hibridnost.

In the colonial world, the "two different species" (Fanon 1963: 40) immediately visible as its inhabitants are those of the oppressor and the oppressed. As Fanon described it, it is a world cut in two, with a dividing line of barracks and police stations (Fanon 1963: 38). The two opposing sides appear to cohabitate the same planet, but only in theory: "The zone where the natives live is not complementary to the zone inhabited by the settlers. The two zones are opposed, but not in the service of a higher unity. ... No conciliation is possible, for of the two terms, one is superfluous." (Fanon 1963: 38-39) In such a world of black and white, as in every aspect of life, somewhat of a grey area appears, both literally and metaphorically.

Webster's Encyclopedic Dictionary of the English Language, as the second of its three suggested definitions of the term hybrid, defines it as "a person whose background is a blend of two diverse cultures or traditions". In Key Concepts in Post-Colonial Studies the term hybridity is defined as "One of the most widely employed and disputed terms in post-colonial theory" which "commonly refers to the creation of new transcultural forms within the contact zone produced by colonization." (Ashcroft 1998: 118).

1 Kontakt podaci (Email): bojanagledic@gmail.com 
The dispute mentioned in the definition refers to the disagreement among certain scholars as to whether this term is appropriate for use in colonial discourse. On the one hand, those who advocate for the use of the term, like Homi K. Bhabha, who is thought to have coined it, perceive it as a term defining a natural and inescapable blending of two cultures in contact, which by no means eradicates the existence of the individual cultures as such (Ashcroft 1995: 184). In his book entitled The Location of Culture Homi K. Bhabha introduces the definition of what he calls the "Third Space" which is where this intermixing of cultures takes place. It exists between the already determined and constantly present "first" and "second" spaces which are always opposed in the colonial context. According to Bhabha, the production of meaning takes place in this "Third Space" which erases the purity of cultures (Bhabha 1994: 37).

Scholars who oppose the use of the term point out two main reasons. Firstly, the term used to be associated with racism, more specifically the "cross-breeding" between cultures which was paradoxical in itself - sexual relations between races were considered unnatural, but on the other hand necessary (Young 1995: 93-103). Secondly, they believe that the use of such a term attempts to erase the existence of crucial differences and place everything in a colonizing setting in favour of the colonizer (Ashcroft 1998: 119).

Taking into account these different views, one may conclude that the term has so many possible definitions it does not necessarily need to be read as offensive. In this paper, the term will be used in a positive sense, as the definition in Key Concepts in PostColonial Studies ends, stating that theories of the hybrid nature establish a different form of resistance (Ashcroft 1998: 121). The emergence of a hybrid nature shifts the existing categories and brings into question the main postulates of the colonial world.

J.M. Coetzee's Waiting for the Barbarians has been described as "a novel about a man of conscience seeking to disentangle himself from, and oppose, an imperial regime" (Head 2009: 48). The author himself has described it as a novel about torture in his essay entitled "Into the Dark Chamber: the Writer and the South African State" (as per Head 2009: 50). The title was taken from a poem of the same name by the Greek poet C. P. Cavafy (1863-1933). The poem identifies the contradictory dependence on the other, and this idea is in harmony with the topics the novel deals with. For me personally, the title of the novel echoes that of Waiting for Godot, because neither Godot nor the barbarians arrive at the end, bringing into question the existence of either.

The key topics addressed in the novel are violence and torture, which make the difference between the roles of the oppressor and the oppressed bluntly and unpleasantly obvious. Setting them aside, this paper will place emphasis on the seemingly hybrid components of the Magistrate's identity. Evidence in the text itself will be used to prove that the Magistrate indeed does show some ambiguity of character.

At first sight, among all the violence and the irreversibly damaged people, physically more than emotionally, the character of the Magistrate may appear as just a voice telling a terrible story. One would expect, since he approaches the reader from the side of the oppressor, that the narration will take its course naturally and without interruptions but, even though his descriptions remain vivid, forcing the reader to occasionally cringe with horror, from the very start it is visible that something is about to change and that the Magistrate might be on the verge of experiencing a change of 
character/opinion/heart. It is much easier to track these changes through the intimate narration of the first person singular.

Although I myself would not go as far as to state that the Magistrate has a sympathetic and congenial nature and that he cares for the barbarians, firmly believes they are innocent and helps them, as Mushtaq (2010: 29) does in his paper which, among other things, addresses this issue, one may claim with certainty that there is enough evidence throughout the novel that a strong change is taking place in the Magistrate's character. This change stems from an unfortunate turn of events, one that takes place after decades the Magistrate has spent deceiving himself. It begins when he is no longer able or no longer wishes to remain in the dark about certain practices in the settlement. Once this door is opened, he can never go back to what he used to be; he has been infected by new knowledge and, once having shed light on a different form of truth, he can never go back to being his old self (Coetzee 2004: 22-23). According to Bhabha (1994: 115) "...the existence of two contradictory knowledges (multiple beliefs) splits the ego (or the discourse) into two psychical attitudes, and forms of knowledge, towards the external world."

Before venturing further into a presentation of the Magistrate's newly formed, hybrid identity, let us mention quickly the remains of the "old", presumably colonial identity. In favour of him not being truly changed, one may argue that perhaps his periodical bouts of regret depicted in the novel might only show a periodically guilty conscience of the coloniser, showing that they too are only human. One may also argue that, not having been in the capital for centuries, he has lost touch with "the civilised world". His relationship with the barbarian girl might also be read in two ways - he might be willing to alleviate her condition, forced forward by his guilty conscience, or he might just be the coloniser who is smitten with the dark secrets of exotic young women, who were, aside from the assets, perhaps the most attractive "feature" of the colonies (Young 1995: 102). Finally, although he attempts at one point to help some of the barbarians, in the end one's final conclusion might be that he has given up.

Throughout the novel, the reader never learns the Magistrate's name, which basically places him in the category of Everyman. As the novel opens, the reader does not feel that the man had any choice in the matter - he is on the border because, in his world, it seemed like the natural thing to do. His position as Magistrate is clear, there is no doubt about that. He serves as a go-between of a sort, and, in his own words, he wanted nothing more than to live "a quiet life in quiet times" (Coetzee 2004: 8). He remembers 'the old days' with some melancholy, although it is clear from his narration that even in the course of those 'carefree days' he engaged in practices which would be frowned upon by advocates of human rights. He himself mentions feeling "uneasy shame" (Coetzee 2004: 152) at passing sentences to prisoners, but when these new events have taken place he thinks with yearning of the "familiar routine of his duties" (Coetzee 2004: 81).

As the novel opens, the arrival of Colonel Joll causes a stir in the Magistrate's familiar surroundings. For some reason, which remains unclear in the novel, he decides to go and see what really happened to a couple of prisoners. It remains unclear in the text as to why he does this, there is no clear history of the events which brought him to such a state. For this reason, one might claim that this episode is only a temporary bout of a guilty conscience. It is more desirable to think that it is not. 
At certain points in the novel, the Magistrate indicates that what brought him to that state was a higher force at work, and that it had nothing to do with free will. First he feels that he never wished to be drawn into that (Coetzee 2004: 8), then toys with the idea that he might even not be present (Coetzee 2004: 30), further claiming that he was a victim of the randomness of fate - something had fallen in upon him from the sky, from nowhere (Coetzee 2004: 47), finally saying that he was only doing his duty, and then one day events overtook him (Coetzee 2004: 153).

As far as questioning authority is concerned, the Magistrate embarks on a journey of no return. His sudden curiosity buys him a one-way ticket to personal and professional disaster. He opens a door which he can never close again, unless we take the ending of the novel as a return to the old ways. The ending is somewhat ambiguous - he is taking "a road that may lead nowhere" (Coetzee 2004: 170). This use of a strong modal possibility is one of the key indicators that there are hybrid elements in the Magistrate's character. The entire year described in the novel is a year of dilemmas and uncertainties. Towards the end, it seems that he has finally come to terms with having made a whole lot of mistakes, but then there is this "may" at the end which leaves everything open for discussion. Marais (1996: 81) was certainly not alone in his opinion when he declared Coetzee's writing resistant to "interpretative strategies of containment". Like the space and time in this novel, many other elements of Coetzee's fiction elude the reader and the critic alike.

Be that as it may, it is possible to determine several different aspects in which the possible hybridity of the Magistrate's character is visible. Firstly, there is the contempt that he feels for Colonel Joll. At the beginning of the novel, he doubts his authority and the importance he attributes to himself (Coetzee 2004: 2), but even though he has his doubts, he entertains the Colonel as well as he can, hating himself for it when he goes too far, because they do not need to love each other, he only needs to perform his duty (Coetzee 2004: 6). Further on in the story, after describing the Colonel as a "burden" (Coetzee 2004: 14) the mixed feelings of subordination and disapproval from the beginning of the novel turn into real hatred. He goes so far as to accuse the Colonel of being the enemy (Coetzee 2004: 125) denouncing all connections with him, and during their last encounter the Magistrate feels an urge to beat the Colonel's body to pulp (Coetzee 2004: 160). According to Bhabha (1994: 113), this questioning of authority and hatred towards the policy of Empire is one of the clear signs of an onset of a hybrid character.

The second visible change takes place in the Magistrate's character when he is no longer able to pretend everything is alright with the world. After he finds out what happened to the prisoners, he experiences something new - he informs the reader that he has never had the feeling of not living his own life on his own terms (Coetzee 2004: 43). His troubled thoughts are so strong that he expects an impossible physical manifestation of what he feels, a physical sign of the pain and suffering on the empty walls (Coetzee 2004: 87). At certain points in the novel, the Magistrate indicates that at least in some periods of his life he did not think of the barbarians as an underdeveloped species. He claims that he based his conduct on the non-corruption of barbarian virtues and not making them a dependent people (Coetzee 2004: 41). His taking sides with the barbarians reaches its peak on two occasions. The first is when, against his better 
judgement, he decides to return the barbarian girl to her people, intending "to restore some of the goodwill that previously existed" (Coetzee 2004: 62). Somewhere at the back of his mind he knows what will probably happen upon his return to the settlement, but nevertheless, before undertaking the journey he feels content and relieved (Coetzee 2004: 63). After finishing the set task he feels that the oppression lifted from his shoulders (Coetzee 2004: 74). The second occasion is when he intervenes in the torture event taking place right outside the town walls. In this situation, he himself is a prisoner who has broken out of prison, but nevertheless decides to draw attention to himself when he tries to stop the brutal beatings and gets beaten and almost blinded in return. Even though he feels that he should not have left his cell, the other side of him believes he could have done more, and he is angry with himself for not persevering (Coetzee 2004: 118).

The Magistrate's relationship with the girl is where the changes taking place in his character are most clearly visible. He experiences a mixture of feelings, and throughout all the months they spend together he seems not to have resolved his dilemma; he is angry with himself for wanting her and not wanting her at the same time (Coetzee 2004: 35). The grounding for this strange relationship could perhaps be found in his trying to come to terms with himself and his own beliefs through his relationship with an immediate victim of the regime he once seemed to support. He admits that he has not "ceased to see her as a body maimed, scarred, harmed..." (Coetzee 2004: 61) and that he has no idea why he is spending time with her. He suspects that it might be his guilty conscience, but is not sure; he asks himself whether he desires her or her scars and wonders about the obscurity of his reasons for spending time with her (Coetzee 2004: 70). Continuing the argument from above that at certain points he stops seeing himself as something different from the barbarians, with regards to his relationship with the girl it is important to mention the different stages of self-doubt he experiences. First, he frequently questions his 'distance' from the people who mutilated her and realises that the distance between himself and her torturers is "negligible" (Coetzee 2004: 29). Then, he takes a step further and hates himself for being with her because he feels her to be superior, he feels that he is "...acid in milk, ashes in honey, chalk in bread" (Coetzee 2004: 36). Finally, he practically sees the barbarian girl as his equal and it all boils down to him asking himself what he meant to her, as a man, and whether she found him ordinary (Coetzee 2004: 61).

The fourth visible sign of the Magistrate's hybrid identity are the bad dreams he constantly has. He admits that sleep no longer brings peace to his troubled mind (Coetzee 2004: 22). Some nights are oblivion, but others take him to unexpected places, and the novel includes a description of a total of eight dreams. In all his dreams he sees the barbarian girl, she is the central figure in each and every one of them. His obsession with her is best presented in these products of the unconscious. Some aspects of the dreams are sexual, other aspects show how uneasy he feels. The good and bad images follow one another in his dreams, just like the two sides of his character interchange, which brings us to the last aspect of hybridity in the Magistrate's character.

On the one hand, the Magistrate knows his place in history and understands that he is not the opposite of Colonel Joll, but just a different side of Imperial rule. He describes himself as "the lie that Empire tells itself when times are easy" (Coetzee 2004: 13). He 
believes that he is "a go-between, a jackal of Empire in sheep's clothing" (Coetzee 2004: 79), he has his doubts about how the girl sees him (Coetzee 2004: 89), but at times when his mind is clear, he is determined to remove himself from the path Empire has taken and states that there is nothing to connect him with the torturers, and that he will not pay for someone else's crimes (Coetzee 2004: 48). He renounces his alliance with the Empire and declares himself a free man (Coetzee 2004: 85). He clearly shows how repulsed he is by the deeds of the torturers, he cannot imagine how they live and eat (Coetzee 2004: 138). All these instances of personal rebellion are a potential sign of the Magistrate's hybrid identity, because, according to Bhabha (1994: 114), when we talk about hybridity, "the presence of colonialist authority is no longer immediately visible". Even though the Magistrate claims, more frequently than not, that he never thought the domestic population less civilised than his own, throughout the entire novel, as soon as such thoughts start to invade his mind, they are followed by feelings of doubt as to what his real motives are; he is not certain that he believes in what he has been saying (Coetzee 2004: 56) and wonders whether he is nothing but an old man who does not wish to be disturbed in the last years of his life (Coetzee 2004: 56). Troubled by these tangled thoughts, he is not sure that alienating himself from his own people is what he needs to do, he doubts himself and the righteousness of his cause (Coetzee 2004: 104105). While imprisoned, he does not want to suffer torture if he is not sure anymore about what cause he is defending (Coetzee 2004: 105).

These two opposing sides of his character cause great confusion, and he often mentions that he does not know who he is, what is happening or what he believes in anymore, he defends himself by believing he is a confused and innocent person, a "baby" (Coetzee 2004: 103). He longs for clarity of mind and does not wish to die so "stupid and befuddled" (Coetzee 2004: 103). He feels that the girl could have been the solution, had he realised it sooner (Coetzee 2004: 13). The only space where one may place the Magistrate in such a state of confusion is somewhere in between, in the Third Space that Bhabha introduced. The stirrings of this troubled mind also fit into Young's definition of hybridisation, according to which a single entity is divided in two and sameness is turned into difference (Young 1995: 24). As the novel ends, the Magistrate does not find his peace. He believed that he was on a road that was true but instead was delivered "into the heart of a labyrinth" (Coetzee 2004: 149). There is nothing else for him to do but patiently wait for barbarians who may or may not come, and who may not even exist.

This paper has presented that in J. M. Coetzee's Waiting for the Barbarians, there is abundant evidence in the text itself that presents the Magistrate as a man of the law and a loyal subject of Empire who does not question his role and his cause. There is just as much evidence that presents him as simply a victim of a troubled mind, a man oppressed by a guilty conscience, a person unable to view the world in black and white, a human being incapable of mindless hatred. It is impossible to strictly categorise the Magistrate as any of the two species mentioned at the very beginning. His character has too many diverse and opposing traits/thoughts/beliefs for either. His psyche slowly travels throughout the novel and towards the end reaches an unfamiliar final destination. He is neither here nor there, the only place left for one to place him in is at the end of the hybridisation process, in the Third Space which eludes the politics of polarity (Bhabha 1994: 39). As we leave him, he is still "...a creature that believes in nothing" (Coetzee 2004: 89), but it seems 
that after all the self-doubt he will find his place wherever the obscure road takes him, because as the novel ends one may conclude that the greatest danger to a man's sanity lies in hiding away from the truth, whatever it may be.

\section{REFERENCES}

Ashcroft, B. et al. 1998. Key Concepts in Post-Colonial Studies. London and New York: Routledge.

Ashcroft, B., G. Griffiths and H. Tiffin (eds.). 1995. The Post-Colonial Studies Reader. London and New York: Routledge, 183-209.

Bhabha, H. 1994. The Location of Culture. London and New York: Routledge.

Coetzee, J.M. 2004. Waiting for the Barbarians. London: Vintage Books.

Fanon, F. 1963. The Wretched of the Earth, trans. by C. Farrington. New York: Grove Press. Head, D. 2009. The Cambridge Introduction to J. M. Coetzee. Cambridge: CUP, 48-55.

Marais, M. 1996. Critical Perspectives on J. M. Coetzee. In G. Huggan and S. Watson (eds.) The Hermeneutics of Empire: Coetzee's Post-Colonial Metafiction. London: Macmillan Press, 66-81.

Mushtaq, H. 2010. 0thering, Stereotyping and Hybridity in Fiction: A Postcolonial Analysis of Conrad's Heart of Darkness (1899) and Coetzee's Waiting for the Barbarians (1980). Journal of Language and Literature 3/August, 25-30. [Internet]. Available at: http://papers.ssrn.com/sol3/papers.cfm?abstract_id=1679116 [15.05. 2011].

Young, R. 1995. Colonial Desire. London and New York: Routledge.

Webster's New Explorer Encyclopedic Dictionary. 2006. Springfield, MA: Merriam-Webster.

\section{SUMMARY}

\section{HYBRIDITY IN J. M. COETZEE'S WAITING FOR THE BARBARIANS}

In the colonial world, the dividing line between the space of the oppressor and that of the oppressed is clearly visible. In such a setting, there is at times emergence of a no man's land inhabited by hybrids. This paper investigates the possibilities of an ongoing hybridisation process in J. M. Coetzee's 1980 novel Waiting for the Barbarians. It gives an overview of the definitions and the use of the term hybrid and presents the possible application of such a term to the Magistrate's character in the aforementioned novel. Different questionable and ambiguous aspects of the character's behaviour are taken into consideration, and the conclusion is reached that these indicate that by the end of the novel there are doubtless signs of hybridity in the Magistrate's character.

KEYWORDS: colonial identity, superiority, otherness, hybridity.

(Original scientific paper received 29.01.2012; revised 21.09.2012; accepted 21.09.2012) 